\title{
Working
}

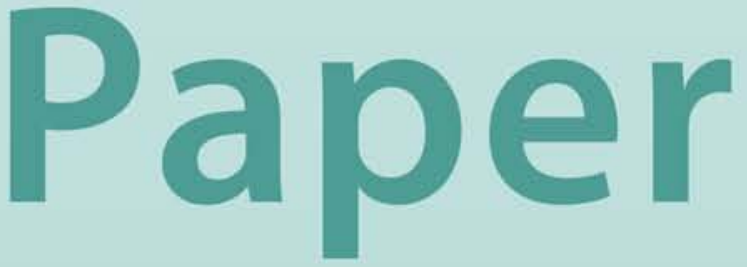




\section{Automatic Stabilizers and the Size of Government: Correcting a Common Misunderstanding}

Carlo Cottarelli and Annalisa Fedelino 


\title{
IMF Working Paper
}

Fiscal Affairs Department and Office of Budget and Planning

\section{Automatic Stabilizers and the Size of Government: Correcting a Common Misunderstanding}

Prepared by Carlo Cottarelli and Annalisa Fedelino ${ }^{1}$

July 2010

\begin{abstract}

\section{This Working Paper should not be reported as representing the views of the IMF.} The views expressed in this Working Paper are those of the author(s) and do not necessarily represent those of the IMF or IMF policy. Working Papers describe research in progress by the author(s) and are published to elicit comments and to further debate.
\end{abstract}

The size of government is a commonly used variable in many analytical studies on the effects of fiscal policy. An accepted practice is to measure it as the ratio of government spending to GDP. However, this is not the correct metric when computing the stabilization effects of nondiscretionary fiscal policy. Intuitively, public spending does not react to cyclical conditions as much as taxes do-as reflected in the standard zero-one elasticity assumptions for spending and revenue, respectively. This paper shows that the revenue to GDP ratio is the appropriate indicator of government size for the purpose of assessing the stabilization effects of nondiscretionary fiscal policy.

JEL Classification Numbers:E60, H62, H69

Keywords: Fiscal policy, automatic stabilizers, cyclical adjustment

Author’s E-Mail Address: ccottarelli@imf.org; afedelino@imf.org

\footnotetext{
${ }^{1}$ We would like to thank Xavier Debrun and Richard Hemming for discussing with us the issues covered in this paper; and Fabrizio Balassone, Julio Escolano, Mark Horton, Andrea Schaechter and a number of colleagues in the Fiscal Affairs Department for useful comments on an earlier draft. Raquel Gomez Sirera provided excellent research assistance. The usual disclaimer applies.
} 


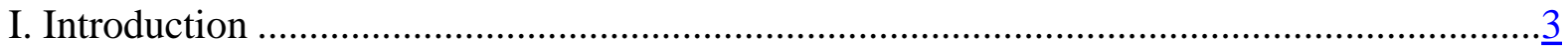

II. Why is the Literature Focusing (Mostly) on the Spending Ratio? ......................................

III. Something is Counterintuitive …......................................................................

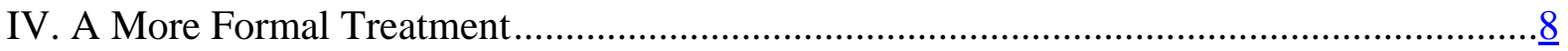

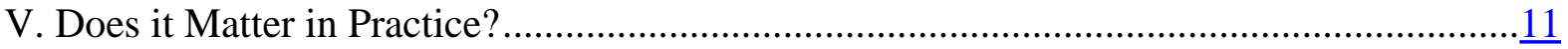

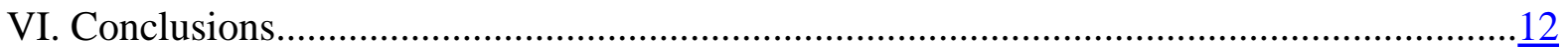

Tables

1. Income Shocks and Fiscal Balances (No Spending, as a Share of GDP) ...........................

2. Income Shocks and Fiscal Balances (Nonzero Spending, as a Share of GDP) ....................

3. Income Shocks and Fiscal Balances (No Spending, as a Share of Potential GDP)..............

4. Income Shocks and Fiscal Balances (Nonzero Spending, as a Share of Potential GDP)...... 7

5. Measurement Error for Top 50 Economies, 2000-10 ..................................................11 


\section{INTRODUCTION}

A rising body of literature has tried to assess the effect of the size of government on the volatility of economic activity (Galì, 1994, Fatás and Mihov, 2001, Debrun, Pisani-Ferry and Sapir (2008), Debrun and Kapoor, 2010). The argument is that, the larger the size of government, the larger is the effect of the automatic stabilizers and therefore, the greater is the nondiscretionary fiscal policy response in support of economic activity in a downturn (and vice versa in a boom). In this literature, the size of government is often (although not exclusively) measured by the ratio between spending and GDP (henceforth the "spending ratio"), which is used as a proxy for the magnitude of automatic stabilizers in econometric regressions where the dependent variable is the volatility of the growth rate of GDP. More generally, the same ratio is used by various analysts as a proxy for the magnitude of the automatic stabilizers. What is puzzling — and counterintuitive - is that the spending ratio is used as the relevant measure of the magnitude of the automatic stabilizers under the simplifying (but commonly applied) assumption of zero elasticity of spending and unit elasticity of revenues (both to the output gap), that is, under the assumption that the only variable that responds to cyclical movements is revenues, not spending.

In this paper, we show that the correct measure of the size of the automatic stabilizers is the revenue-to-GDP ratio (henceforth "the revenue ratio") if the goal is to assess how the size of government affects the volatility of GDP growth rates. More specifically, we show that the focus on the spending, rather than the revenue, ratio arises from the assumption that the best measure of the impact of fiscal policy on the economy is the change in the deficit-to-GDP ratio. This assumption is a useful simplification in monitoring fiscal developments, but is inadequate in analytical studies aimed at assessing output volatility. For analytical purposes, the effect of fiscal policy on the GDP growth rate depends on the change in the deficit with respect to GDP in the previous year (not the change in deficit ratio). If so, the paper shows that the revenue ratio, not the spending ratio, is the correct measure of the government size.

Does this matter in practice? Standard "errors in variables" analysis suggests that the bias in the estimation of the coefficient on the size of government is unlikely to be large. However, as revenue-to-GDP data are as readily available as spending-to-GDP data, there is no justification for using the wrong variable in future econometric studies.

\section{Why IS The Literature Focusing (Mostly) ON THE SPENDING RATio?}

The automatic stabilizers represent the nondiscretionary component of fiscal policy and are the focus of a broad branch of the economic literature on the effects of fiscal policies, typically to assess their impact on output volatility. The automatic stabilizers depend on the extent to which revenues and spending change in response to movements in GDP (changes in the output gap), which in turn is a function of the elasticity of these variables and on their size in relation to GDP. For given elasticities, the larger the size of government, the larger the automatic stabilizers, and the more stable GDP should be. 
Studies on the stabilization role of fiscal policy have rather liberally used both the spending and revenue ratios as measures of government size. Galì (1994) measures government size both as "the average share of government revenue and purchases in GDP." Regardless of the variable used, the same conclusion derives - that countries with large governments have experienced milder economic fluctuations compared to countries with smaller governments. Fatás and Mihov (2001) revisit the relationship between government size and the volatility of the business cycle for two reasons: government size (measured by either revenue or spending ratios) is strongly correlated with conventional measures of automatic stabilizers; and "the size of government spending might in itself be a significant determinant of the characteristics of business cycles.” Interestingly, while they recognize upfront that automatic stabilizers act via the ability of taxes and transfer to stabilize disposable income, their empirical analysis starts with a measure of government size based on the average ratio of spending to GDP; alternative measures of government size are later used, defined as ratios of spending items as well as revenue (and revenue items) to GDP. ${ }^{2}$ They also acknowledge that total government spending is highly correlated with taxes, hence it is difficult to distinguish whether the significance of spending-related variables derives from the fact that these act as proxy for taxes (an issue we will explore in Section V).

In a similar vein, the spending ratio is used by Andrès, Domènech, and Fatás (2007) as a measure of government size. Virèn (2005) applies various measures of government size to assess the latter's relationship with output volatility; he concludes that this relationship is more robust when the revenue ratio is used, although this empirical result is not explained analytically. Silgoner, Reitschuler and Crespo-Cuaresma (2002) and Lee and Sung (2007) use the expenditure ratio to study again the (possibly nonlinear, in the former study) relationship between government size and output volatility. Mohanty and Zampolli (2009) use both spending and revenue ratios as measures of government size, although results are shown only for the former, possibly suggesting this is the preferred measure.

These studies, however, do not make an explicit assumption about revenue and expenditure elasticities - a gap filled by Debrun, Pisani-Ferry and Sapir (2008) and Debrun and Kapoor (2010). There, the use of the spending ratio as an "adequate” measure of automatic stabilizers is derived from the standard assumption of zero-one elasticity of spending and revenue to the output gap, respectively, given that "the public expenditure ratio is the semielasticity of the budget balance (in percent of GDP) to the output gap.”

\footnotetext{
${ }^{2}$ This applies to their analysis of cross-country data; their analysis of "intranational data" (based on the U.S. states) relies more on measures of government size based on tax revenues (partly because of the difficulty of disentangling expenditure data by state).
} 


\section{SOMETHING IS Counterintuitive}

The conclusion that the spending ratio is the right measure of the government size under the assumption of unit elasticity of revenues and zero elasticity of spending is counter-intuitive. Assuming the spending elasticity is zero (or low), the tax system determines the way in which a shock to gross income is reflected into a change in disposable income-a result highlighted by Darby and Mélitz (2008). For instance, with a flat income tax with a rate of 20 percent, a shock on gross income of one dollar leads to a decline in disposable income of 80 cents. In this case, the (lower) tax burden absorbs 20 percent of the shock to gross income. ${ }^{3}$ Assuming disposable income affects aggregate demand (and hence GDP), the fact that the impact on disposable income of an initial income shock is muffled by the tax system implies that the effect on demand induced by an income shock is mitigated.

Thus, there seems to be something wrong in using the spending ratio as a measure of automatic stabilizers, particularly when the elasticity of spending is explicitly assumed to be zero.

A simple example can illustrate why using the spending ratio to measure the size of the automatic stabilizers is inappropriate. For simplicity, we assume, as others, that the revenue elasticity is one and that spending elasticity is zero. Indeed, to simplify things further, we focus, first, on a case of a (misfortunate or altruistic) country where the government just collects taxes at a rate of 30 percent of pre-tax income and does not spend anything domestically (the money could be accumulated in a fund for future spending or be transferred abroad, say, in support of needy countries).

In this country, by construction the spending ratio is zero and the revenue ratio is 30 percent. Using the standard measure of the size of government as a proxy for the size of the automatic stabilizers, we would conclude that the size of the latter is zero: there are no automatic stabilizers in this country.

This is clearly misleading. If, for example, GDP declines from 100 to 90 , as a result of a shock, disposable income of the private sector will decline only from 70 to $63-a$ anit decline against a 10 unit shock: the impact has been mitigated by the existence of taxation and the related decline in the government surplus from 30 to 27 (Table 1). This, in a world with zero spending elasticity and unit revenue elasticity, is what we call "automatic stabilizers."

\footnotetext{
${ }^{3}$ An even stronger effect would be induced by a progressive tax, although Baunsgaard and Symansky (2009) show that the unit elasticity is a pretty good approximation to the effect of the automatic stabilizers even when the tax system is highly progressive.
} 
Table 1. Income Shocks and Fiscal Balances (No Spending, as a Share of GDP)

\begin{tabular}{|c|c|c|c|c|c|c|}
\hline \multirow{3}{*}{ Revenue } & Period 1 & Period 2 & Change & Period 1 & Period 2 & Change \\
\hline & \multicolumn{3}{|c|}{ Nominal } & \multicolumn{3}{|c|}{ In percent of GDP } \\
\hline & 30 & 27 & -3 & 30.0 & 30.0 & 0.0 \\
\hline Expenditure & 0 & 0 & 0 & 0.0 & 0.0 & 0.0 \\
\hline Balance & 30 & 27 & -3 & 30.0 & 30.0 & 0.0 \\
\hline \multicolumn{7}{|l|}{ Memorandum items } \\
\hline Nominal GDP & 100 & 90 & -10 & & & \\
\hline Private sector disp. income & 70 & 63 & -7 & 70.0 & 70.0 & 0.0 \\
\hline
\end{tabular}

If it is so simple, why have many used the spending ratio as a proxy for the size of the automatic stabilizers? The reason is that it is common practice-and a practice entirely justified for simplicity in many circumstances - to describe the conjunctural effect of fiscal policy by looking at the change of the fiscal balance-to-GDP ratio. But this is, analytically, inaccurate. Let's go back to the above example. The surplus-to-GDP ratio in the above example remains constant at 30 percent, which would imply the absence of any supportive action to the economy. This is because the revenue ratio remains constant at 30 percent (given the assumption of unit elasticity) and the spending ratio also does not change (at zero). But, as explained, the automatic stabilizers in the above example play a very effective role, easing the impact on private disposable income arising from the economic downturn.

While the assumption of zero spending is obviously extreme, one does not need to invoke it to show our point. Table 2 includes a more "normal” example, where the only difference from the previous one is that the spending level is 30, which remains fixed when the economy suffers a 10 percent shock in period 2. Again, it seems that the action is on the spending side (the revenue ratio does not change), but as explained above, the nominal decline in revenue allows to mitigate the impact on disposable income.

Table 2. Income Shocks and Fiscal Balances (Nonzero Spending, as a Share of GDP)

\begin{tabular}{|c|c|c|c|c|c|c|}
\hline \multirow{3}{*}{ Revenue } & Period 1 & Period 2 & Change & Period 1 & Period 2 & Change \\
\hline & \multicolumn{3}{|c|}{ Nominal } & \multicolumn{3}{|c|}{ In percent of GDP } \\
\hline & 30 & 27 & -3 & 30.0 & 30.0 & 0.0 \\
\hline Expenditure & 30 & 30 & 0 & 30.0 & 33.3 & 3.3 \\
\hline Balance & 0 & -3 & -3 & 0.0 & -3.3 & -3.3 \\
\hline \multicolumn{7}{|l|}{ Memorandum items } \\
\hline Nominal GDP & 100 & 90 & -10 & & & \\
\hline Private sector disp. income & 70 & 63 & -7 & 70.0 & 70.0 & 0.0 \\
\hline
\end{tabular}


This would be obvious if, instead of measuring the fiscal variables with respect to current GDP, we measured them with respect to potential GDP (Tables 3 and 4). In the first example, the surplus-to-potential GDP ratio would decline from 30 percent (assuming no output gap in period 1) to 27 percent, which corresponds to the identical decline in the revenue-to-potential GDP ratio (with no change in the spending to GDP ratio; the same decline is evident in the second example, where spending is assumed nonzero). The same result would hold even if we measured the impact of fiscal policy by looking at the surplus-to-previous period GDP (which does not necessarily need to be equal to potential).

Table 3. Income Shocks and Fiscal Balances (No Spending, as a Share of Potential GDP)

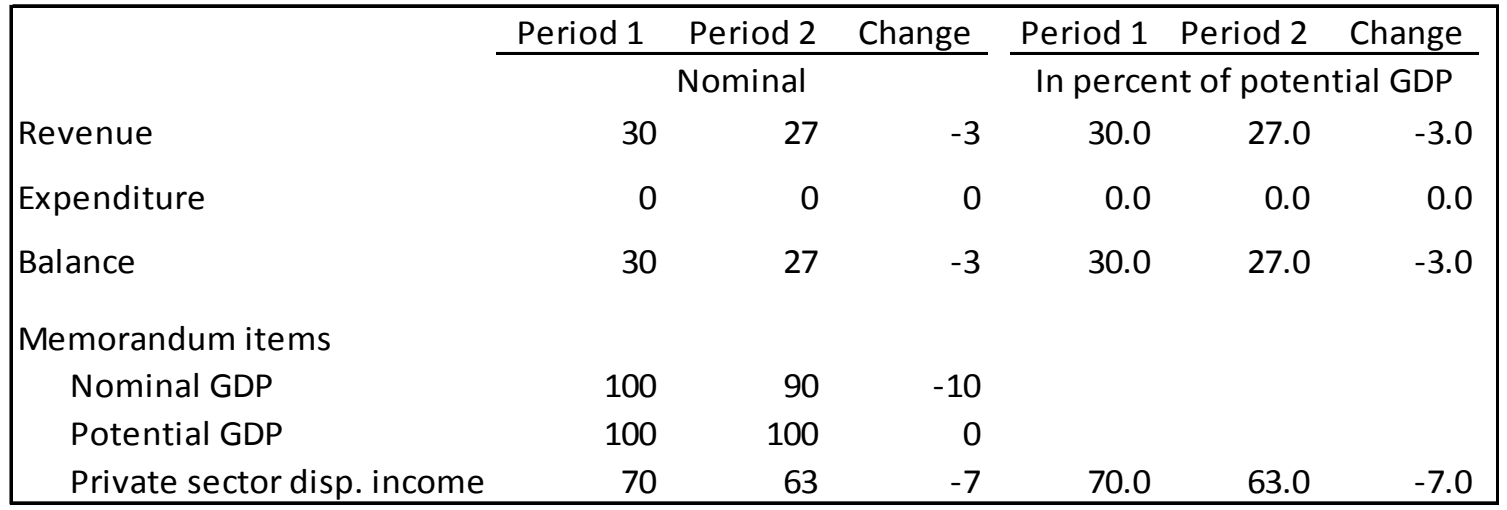

Table 4. Income Shocks and Fiscal Balances (Nonzero Spending, as a Share of Potential GDP)

\begin{tabular}{|lrrrrrrrr|}
\hline & Period 1 & Period 2 & Change & & Period 1 & Period 2 & Change \\
\cline { 2 - 3 } Revenue & 30 & 27 & -3 & 30.0 & 27.0 & -3.0 \\
Expenditure & 30 & 30 & 0 & 30.0 & 30.0 & 0.0 \\
Balance & 0 & -3 & -3 & 0.0 & -3.0 & -3.0 \\
Memorandum items & & & & & & & \\
$\quad$ Nominal GDP & 100 & 90 & -10 & & & \\
$\quad$ Potential GDP & 100 & 100 & 0 & & & \\
$\quad$ Private sector disp. income & 70 & 63 & -7 & 70.0 & 63.0 & -7.0 \\
\hline
\end{tabular}

In general, under the assumption of unit revenue elasticity and zero spending elasticity, changes in the budget balance (surplus or deficit)-to-GDP ratio depend on the spending ratio, not the revenue ratio (hence the common fallacy), while changes in the budget balance-topotential (or previous period) GDP depend on the revenue ratio, not the spending ratio. ${ }^{4}$

\footnotetext{
${ }^{4}$ The focus on spending ratio is sometimes justified with the following argument. Even if the elasticity of spending is zero, the automatic stabilizers operate on the spending size because keeping spending constant when output declines stimulate the economy. This is not convincing. Keeping spending constant simply avoids the
}

(continued...) 


\section{A MORE Formal TREATMENT}

Automatic stabilizers depend on the part of the fiscal balance that is affected by cyclical developments, i.e., by the cyclical fiscal balance (Fedelino, Ivanova and Horton, 2009). The latter can be derived by: (1) computing cyclically-adjusted revenue and expenditure; and (2) subtracting them from the overall budget balance. ${ }^{5}$

The cyclically-adjusted component of revenue $R^{C A}$ is defined as ${ }^{6}$

$$
R^{C A}=R\left(\frac{Y^{p}}{Y}\right)^{\varepsilon_{R}}
$$

where $R$ is nominal revenue, $Y^{p}$ is potential output (that is, the maximum output compatible, at any given time, with a non-accelerating inflation rate) $Y$ is actual output and $\varepsilon_{R}$ is elasticity of revenue with respect to the output gap, gap $=\frac{Y-Y^{p}}{Y^{p}}$.

Similarly, cyclically-adjusted expenditure is defined as

$$
G^{C A}=G\left(\frac{Y^{p}}{Y}\right)^{\varepsilon_{G}}
$$

where $G$ is nominal expenditure and $\varepsilon_{G}$ is the elasticity of expenditure with respect to the output gap.

On this basis, the cyclically-adjusted balance $(C A B)$ is

\footnotetext{
procyclicality of fiscal policy_adding to the decline in private sector demand a decline in public sector demand, but it could hardly be seen as providing an automatic expansionary impact. If keeping spending constant were seen as providing an expansionary impact, then a cut in spending would have to be regarded as cyclically neutral, which would be paradoxical.

${ }^{5}$ For simplicity, we do not distinguish between overall spending and primary spending (and revenue). There are, however, reasons in favor or against separating out interest payments when performing cyclical adjustment (they may or not contain some component correlated with the cycle)-in either case, the analytical results in this section would not change.

${ }^{6}$ This is a simplified version of OECD (Girouard and André, 2005) and European Commission (Bouthevillain and others, 2001) methods, which use separate components of revenue to compute cyclically-adjusted revenue and adjusts expenditures based on the deviation of the actual level of unemployment from structural unemployment. In the absence of more detailed information on revenue/expenditure components, cyclical adjustment can be performed on total revenue and spending by applying aggregate elasticities.
} 


$$
C A B=R\left(\frac{Y^{p}}{Y}\right)^{\varepsilon_{R}}-G\left(\frac{Y^{p}}{Y}\right)^{\varepsilon_{G}}
$$

Scaled down (3) by $Y^{p}$, (3) can be rewritten as

$$
\begin{aligned}
& c a b^{*}=\frac{R\left(Y^{p} / Y\right)^{\varepsilon_{R}}}{Y} \frac{Y}{Y^{p}}-\frac{G\left(Y^{p} / Y\right)^{\varepsilon_{G}}}{Y} \frac{Y}{Y^{p}} \\
& =r\left(Y^{p} / Y\right)^{\varepsilon_{R}-1}-g\left(Y^{p} / Y\right)^{\varepsilon_{G}-1}
\end{aligned}
$$

where small letter indicate ratios ( $r$ and $g$ are, respectively, the revenue and spending ratio to nominal GDP, and a star indicated a ratio to potential GDP).

If the revenue elasticity is equal to one and expenditure elasticity is equal to zero, then

$$
\begin{aligned}
c a b^{*} & =r-g\left(Y^{p} / Y\right)^{-1} \\
& =b-g\left(Y^{p} / Y\right)^{-1}+g \\
& =b-g\left(Y / Y^{p}-1\right) \\
& =b-g \times g a p
\end{aligned}
$$

where $b$ is the overall budget balance ratio to nominal GDP $(b=r-g)$. From (5), the cyclical balance is simply given by

$$
\begin{aligned}
c b & =b-c a b^{*} \\
& =g \times g a p
\end{aligned}
$$

or in other words, the expenditure ratio is the semielasticity of the budget balance (in percent of GDP) to the output gap.

This explains why the spending ratio is often used as a proxy for automatic stabilizers.

However, results would have been different had one used potential output consistently as the scaling variable - the "natural" choice as cyclically-adjusted balances measure the fiscal balance that would prevail if the output were at its potential level. Formally, the top part of (5) can also be written (see Fedelino, Ivanova and Horton, 2009) as:

$$
c a b^{*}=r-g(1+g a p)
$$


The cyclical balance when all variables are scaled by potential GDP is as follows ${ }^{7}$

$$
\begin{aligned}
& c b^{*}=\frac{C B}{Y^{p}}=\frac{B}{Y^{p}}-\frac{C A B}{Y^{P}}=b^{*}-c a b^{*} \\
& =r(1+g a p)-g(1+g a p)-r+g(1+\text { gap }) \\
& =r \times g a p
\end{aligned}
$$

or in other words, the automatic stabilizers are a function of the revenue to GDP ratio.

The focus on the deficit-to-GDP ratio is a convenient simplification for many practical purposes. The ratio is the focus of the budgetary process and is easily understood, it does not require an estimate of potential output, and its change is in any case close to the change in the deficit-to-potential GDP ratio.

Yet, the impact of fiscal policy on the growth rate of the economy does not depend on the change in the deficit to GDP ratio, but on the change of the deficit as a ratio of the previous year GDP. ${ }^{8}$ This is important because the volatility of the growth rate is precisely the focus on the papers using the spending ratio as a proxy for the size of government.

For simplicity, let us assume that output is equal to private consumption (C) and public spending (G) (private investment and net exports can be omitted without loss of generality):

$$
Y=C+G
$$

and $C=a+c(Y-T)$, where $T$ are net taxes, $Y$-T is disposable income, $c$ is the marginal propensity to consume, and $B=T-G$ is the budget balance. Standard Keynesian multiplier analysis implies that:

$$
Y=\frac{a+(1-c) T-B}{1-c}
$$

and, after lagging (13) by one period, the growth rate of GDP (g) is:

$$
g_{y}=\frac{T-T_{-1}}{Y_{-1}}-\frac{B-B_{-1}}{Y_{-1}(1-c)}
$$

so that the impact of the budget position on the growth rate is measured with respect to the previous year nominal GDP. Thus, the effect of fiscal policy on the GDP growth rate

\footnotetext{
${ }^{7}$ The formula that approximates automatic stabilizers based on the spending ratio uses a mixture of nominal GDP and potential GDP as scaling variables, as shown in equation 5.

${ }^{8}$ A similar argument can be made with respect to the impact of fiscal policy on the output gap.
} 
depends on the change in the deficit with respect to GDP in the previous year (not the change in deficit ratio, as usually assumed for simplicity). ${ }^{9}$ More generally, we make the point that, if one wants to measure the impact of fiscal policy on growth, basic multiplier analysis indicates that the correct scaling variable is GDP in the previous period, which, as shown earlier, implies that the size of the automatic stabilizers in any analysis of GDP growth rates should depend on the revenue to GDP ratio, not the spending to GDP ratio (under the simplifying assumption of unit elasticity of revenue and zero elasticity of spending).

\section{Does it Matter in Practice?}

The implications of using the spending ratio rather than the revenue ratio in econometric equations explaining the volatility of output growth (or of the output gap) can be assessed by using the "errors in variables" analysis. It is well known (see, for example, Maddala, 1992, Ch. 11), that the use, as a regressor, of a variable that is inaccurately measured (or, in our case, of the inappropriate variable) involves a bias in the corresponding estimated coefficient.

More specifically, for sufficiently large samples and under the assumption that the error is uncorrelated with the correct regressor (in our case, that the difference between revenue and spending ratio - the deficit ratio - is uncorrelated with the revenue ratio), there is a downward bias that, in the case of a single regressor, increases with the ratio between the variance of the measurement error (in our case, the variance of the deficit ratio) and the variance of the correct regressor (the revenue ratio).

As a simple check, we have computed the relative variance of the deficit ratio and the revenue ratio for the largest 50 economies over the last decade. The results are reported in Table 5, together with the bias as a percentage of the correct coefficient in the case of a simple equation with a single explanatory variable (for multivariate regressions, the bias depends on more complex variances and covariances). The bias varies across years, from a minimum of 13 percent of the correct coefficient to a maximum of 27 percent.

Table 5. Measurement Error for Top 50 Economies, 2000-10

\begin{tabular}{|c|c|c|c|c|c|c|c|c|c|c|c|}
\hline & 2000 & 2001 & 2002 & 2003 & 2004 & 2005 & 2006 & 2007 & 2008 & 2009 & 2010 \\
\hline Var(revenue ratio) (v1) & 130.9 & 122.4 & 115.6 & 110.5 & 111.9 & 117.0 & 117.6 & 106.8 & 120.7 & 104.5 & 106.9 \\
\hline Var (deficit ratio) (v2) & 19.0 & 25.5 & 27.0 & 29.2 & 34.6 & 27.9 & 30.7 & 22.9 & 44.6 & 16.9 & 17.2 \\
\hline $\begin{array}{l}\text { Estimate bias (in percent } \\
\text { of correct coefficient) } 1 \text { / }\end{array}$ & 12.7 & 17.2 & 19.0 & 20.9 & 23.6 & 19.2 & 20.7 & 17.7 & 27.0 & 13.9 & 13.8 \\
\hline
\end{tabular}

Source: Authors' calculations, based on World Economic Outlook data.

$1 /$ Computed as $1 /(1+v 1 / v 2)$.

\footnotetext{
${ }^{9}$ Of course, the standard Keynesian multiplier framework implies that the impact on GDP growth is larger for spending than for revenue changes, as clear from equation (14).
} 
The bottom line is that even in cases when the bias is likely to be relatively small, there is no clear justification to use the spending ratio, as revenue ratios are as readily available as spending ratios.

\section{Conclusions}

This paper has focused on the literature on the stabilization role of fiscal policy, particularly on the relationship between government size and output volatility. It illustrates two simple points: that the appropriate metric to measure the size of government as a proxy for automatic stabilizers is the revenue-to-GDP ratio (while it has become standard practice to use the spending ratio); and that, accordingly, the revenue ratio should be the regressor of choice in econometric exercises on the relationship between government size and volatility of output. While the bias arising from the use of the spending ratios is likely to be relatively small, there is no reason why spending ratios should continue to be used in future studies, given that revenue ratios are as readily available. 


\section{References}

Andrés, Javier, Rafael Doménech, and Antonio Fatás (2008), “The Stabilizing Role of Government Size,” Journal of Economic Dynamics and Control 32: 571-93.

Baunsgaard, Thomas and Steven Symansky (2009), “Automatic Fiscal Stabilizers,” IMF Staff Position Note No 09/23, (Washington, D.C: International Monetary Fund).

Bouthevillain, Carine, Philippine Cour-Thimann, Pablo Hernandez Cos, Matthias Mohr, Mika Tujula, Geert Langenus, Sandro Momigliano and Gerrit Van Den Dool (2001), “Cyclically-adjusted Budget Balances: An Alternative Approach,” ECB Working Papers No. 77 (Frankfurt: European Central Bank).

Darby, Julia and Jacques Mélitz (2008), "Social Spending and Automatic Stabilizers in the OECD,” Economic Policy 56: 715-56.

Debrun, Xavier and Radhicka Kapoor (2010), "Fiscal Policy and Macroeconomic Stability: Automatic Stabilizers Work, Always and Everywhere” IMF Working Paper 10/111.

Debrun, Xavier, Jean Pisani-Ferry, and André Sapir (2008), "Should We Forsake Automatic Stabilization?” European Economy_Economic papers No. 316 (Brussels: European Commission); forthcoming in Buti, Marco, Servaas Deroose and Vitor Gaspar (eds.) The Euro - the first decade, Cambridge University Press.

Fatás, Antonio, and Mihov, Ilian (2001), “Government Size and Automatic Stabilizers: International and Intranational Evidence,” Journal of International Economics 55: 3-28.

Fedelino, Annalisa, Anna Ivanova and Mark Horton (2009) “Cyclically-Adjusted Balances and Automatic Fiscal Stabilizers: Some Computational and Interpretation Issues” IMF Technical Guidance Note No. 5.

Galì, Jordi (1994), “Government Size and Macroeconomic Stability,’ European Economic Review 38: 117-132.

Girouard, Nathalie and Christophe André, (2005) “Measuring Cyclically-Adjusted Budget Balances for OECD Countries,” OECD Economics Department Working Paper No. 434 (Paris: Organization for Economic Cooperation and Development).

Lee Young and Taeyoon Sung (2007), "Fiscal Policy, Business Cycles and Economic Stabilization: Evidence from Industrialised and Developing Countries,” Fiscal Studies 28: 437-62. 
Maddala, G. S. (1992), “Introduction to Econometrics,” Macmillan Publishing Company, New York.

Mohanty, M. S. and Fabrizio Zampolli (2009), "Government Size and Macroeconomic Stability,” BIS Quarterly Review December: pp55-68, (Basle: Bank for International Settlements).

Silgoner, Maria-Antoinette, Gerhard Reitschuler, and Jesus Crespo-Cuaresma (2003), "Assessing the Smoothing Impact of Automatic Stabilizers: Evidence from Europe," in Gertrude Tumpel-Gugerell and Peter Mooslechner (eds.), Structural Challenges for Europe, Edward Elgar.

Virén, Matti (2005), “Government Size and Output Volatility: Is There a Relationship?” Discussion Papers No. 8 (Helsinki: Bank of Finland). 